UDC 577.22

\title{
Focal adhesion kinase (FAK1) regulates SHB phosphorylation and its binding with a range of signaling proteins.
}

\author{
O. V. Dergai , A. M. Yaruchik, A. V. Rynditch \\ Institute of Molecular Biology and Genetics, NAS of Ukraine \\ 150, Zabolotnogo Str., Kyiv, Ukraine, 03680 \\ o.dergai@gmail.com
}

\begin{abstract}
Aim. To investigate an effect of the Focal adhesion kinase 1 (FAK1) expression on the level of tyrosine phosphorylation of an adaptor protein SHB and to find functional consequences of this posttranslational modification. Methods. Recombinant DNA construction, protein expression and purification, human cell transfection, western blot. Results. Expression of FAK1 induces massive tyrosine phosphorylation of SHB adaptor and enhances its interaction in vitro with $\mathrm{SH} 2$ domains of a range of the signaling proteins such as PI3K, $\mathrm{ABL}$, CRK and PLCG1. Additionally we have found that Epstein-Barr virus protein LMP2A can partially mimic the FAK1-mediated effect strongly elevating the efficiency and SHB interaction with the above-mentioned proteins. While the expression of individual proteins elevated SHB phosphorylation level, the co-expression of LMP2A and FAK1 did not display a synergetic effect. Conclusions. FAK1 as well as LMP2A induce SHB tyrosine phosphorylation and enhance its interaction with a set of the signaling proteins.
\end{abstract}

Ke y w o r d s: FAK1, SHB, LMP2A, phosphorylation.

\section{Introduction}

Focal adhesion kinase 1 (FAK1) is an ubiquitously expressed non-receptor tyrosine kinase which is localized to focal adhesion where a cell is attached to the extracellular matrix. FAK1 operates downstream of the cell surface receptors, such as integrins and receptor tyrosine kinases i.e. EGFR, PDGFR, G-protein coupled receptors (GPCR), EPHA2, netrin receptors and LDL receptors [1,2]. Upon incoming activation signal from the above mentioned receptors FAK1 associates with kinase Src, gets phosphorylated by latter and autophosphorylated to gain the maximum of intrinsic kinase activity. Activated FAK1 phosphorylates ACTN1, ARHGEF7, GRB7, RET, WASL and promotes phosphorylation of BCAR1, GIT2 and SHC1, many of these proteins are crucial regulators of the cytoskeleton reorganization, cell spreading, migration, cell cycle progres- sion, and prevention of apoptosis [3-5]. FAK1 is comprised of a centrally located kinase domain flanked by the large $\mathrm{N}$ - and C-terminal non-catalytic domains (Fig. 1).

The N-terminal region of FAK1 contains FERM homology domain, whereas the $\mathrm{C}$-terminal region of FAK1 contains two proline-rich motifs and a focal adhesion targeting (FAT) domain that mediates its discrete localization to focal adhesions upon FAK1 activation [6]. In addition to the function as a kinase, FAK1 also serves as a scaffolding protein. FAK1 contains the binding sites for many signaling proteins (Fig.1). FAK1 was shown to interact with EGFR, PDGFR, Src, Shc, phosphotidylinositol 3-kinase (PI3K), and phospholipase Cg1 (PLC g1), signaling adaptors GRB2 and GRB7, paxillin, tallin $[1,4,7]$.

FAK1 interacts with and gets activated by signaling scaffold SHB[8]. FAK1 and SHB in a concert

(C) 2016 O. V. Dergai et al.; Published by the Institute of Molecular Biology and Genetics, NAS of Ukraine on behalf of Biopolymers and Cell. This is an Open Access article distributed under the terms of the Creative Commons Attribution License (http://creativecommons.org/licenses/by/4.0/), which permits unrestricted reuse, distribution, and reproduction in any medium, provided the original work is properly cited 
Focal adhesion kinase (FAK1) regulates SHB phosphorylation and its binding with a range of signaling proteins.

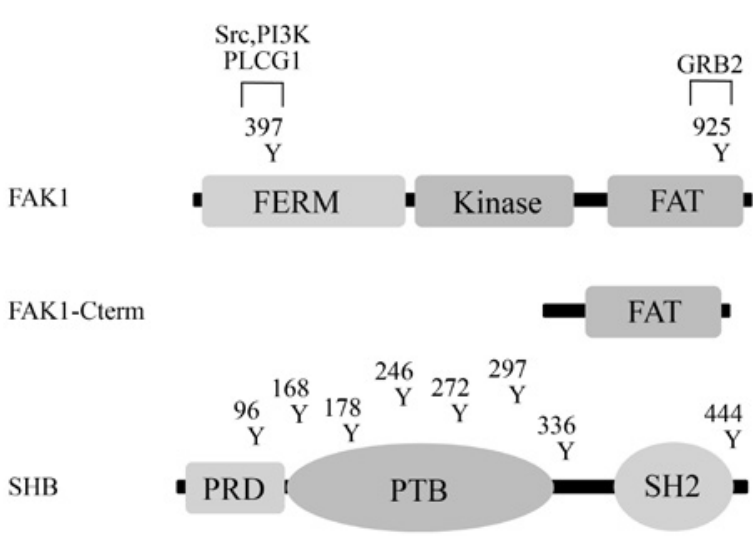

Fig. 1. A schematic representation of FAK1 and SHB proteins. The most important phosphotyrosine sites of FAK1 are shown above with indication of proteins which recognize them. FAK1-C term lacking N-terminal portion with kinase domain is demonstrated below the full-length one. SHB comprises the proline-rich domain (PRD), phosphotyrosine-binding domain (PTB) and $\mathrm{SH} 2$ domain, the two latter domains of SHB are hosphotyrosine-recognition modules. The tyrosine residues predicted by GPS3.0 to be phosphorylated by FAK1 are show above SHB scheme.

regulate the cell spreading and migration [8]. SHB is an ubiquitously expressed protein of about $56 \mathrm{kDa}$ comprising N-terminal proline-rich domain (PRD) which interacts with $\mathrm{SH} 3$ domain of PI3K, phosphotyrosin-binding domain (PTB) and C-terminally located SH2 domain that binds the platelet derived growth factor receptor (PDGFR) and IL-2 receptor and T-cell receptor [8]. Recently SHB was shown to modulate the FAK1 signaling activity in ABL-BCR lymphoproliferative disorder [9]. SHB operates downstream of plasma membrane receptor kinases and participates in AKT/PI3K signaling pathway $[10,11]$.

Here we show that FAK1 can regulate interaction of SHB scaffold with a range of $\mathrm{SH} 2$ domain containing signaling molecules such as CRK, PI3K and c-ABL through the tyrosine phosphorylation of SHB. It has been found that expression of viral protein LMP2A can partially mimic the effect of FAK1 overexpression enhancing binding of SHB to the SH2-domains of CRK, PI3K, GRB2, PLC g1 and c-ABL. An intriguing observation appeared that FAK1 can partially block LMP2A-induced phosphorylation of SHB.

\section{Material and Methods}

\section{Antibodies and plasmids}

Monoclonal antibody to the FLAG epitope (clone M2) was from Sigma; monoclonal $\alpha$-omni (D-8) and $\alpha$-pTyr (pY99) antibodies were from Santa Cruz Biotechnology; a monoclonal $\alpha$-HA (MMS-101P) antibody was from Covance.

Flag-LMP2A and omni-SHB-HA encoding plasmids were described previously [12]. The plasmids encoding GST-fused SH2 domains of PLCG1, PI3K, ABL, GRB2 and CRK were described before [13].

The plasmid encoding HA-FAK1 was kindly provided by Dr. V. M. Golubovskaya [14].

\section{Cell culture and transfection}

293 cells were maintained in Dulbecco's modified Eagle's medium (DMEM) supplemented with 10\% fetal bovine serum, $50 \mathrm{U} / \mathrm{ml}$ penicillin and $100 \mu \mathrm{g} / \mathrm{ml}$ streptomycin. The cells were transiently transfected using JetPEI (Polyplus Transfection) according to the manufacturer's instructions and processed $24 \mathrm{~h}$ after transfection.

\section{Immunoprecipitation}

Cell lysis and immunoprecipitation were performed as described previously [15].

\section{Proteins expression, purification and GST-pull} down assay

GST-fused SH2-domains of PLCG1, PI3K, ABL, GRB2 and CRK were expressed in E.coli BL21 DE3 and affinity purified using glutathione-sepharose $4 \mathrm{~B}$ (GE Healthcare) according to the manufacturer's instructions and further used for the

GST-pull down assays as described before [13].

\section{Results and Discussion}

Taking into consideration the fact that SHB regulates the FAK1 [8] activity through its tyrosine phosphorylation we asked whether there is a reciprocal loop of SHB regulation by FAK1. At first we performed in silico prediction of the FAK1 capability to phosphorylate SHB undertaken by means of GPS3.0 
software (Group-based Prediction System) [16]. According to this analysis 8 tyrosine residues were predicted to be phosphorylated by FAK1 at high stringency, namely Y96, Y162, Y178 Y246, Y272, Y297, Y336, Y444 (Fig.2A). So, we took advantage of the experimental data from PhosphoSitePlus database (http://www.phosphosite.org/) and found that 5 tyrosine residues (namely Y96, Y246, Y272, Y297, Y336) out of 8 predicted ones were found to be phosphorylated in human and mouse samples. Moreover, the indicated five tyrosine residues are conserved in Vertebrates in contrast to tyrosines at the positions Y162, Y178, Y444 (Fig. 2A) To test experimentally the hypothesis that FAK1 may phosphorylate SHB we co-expressed the full-length HAtagged FAK1 or its truncated omni-tagged FAK1Cterm lacking kinase domain (see Fig. 1) together with omni-tagged SHB in 293 cells. The basal level of SHB phosphorylation in 293 cells was below of the detection limit. Despite the equal amount of precipitated SHB (Fig.2B, second panel), a level of its phosphorylation is greatly increased in the cells transfected with full-length FAK1 but not in the cells with expression of FAK1-Cterm lacking a kinase domain (Fig.2B, first panel).

Next, we asked whether the FAK1-induced phosphorylation of SHB has a functional consequence. It's widely accepted that phosphorylation in general serves to switch proteins conformations or to create interaction interfaces which can be recognized by the specialized phospho-binding protein domains. One of the well-known class of phosphotyrosine recognition modules is SH2-domain (Src homology2), which specifically binds the phosphotyrosine residues [17]. Some of the established SHB binding substrates such as GRB2, ABL, PLCg1 contain SH2domain [18]. We studied whether the FAK1-induced phosphorylation of SHB can modulate its interaction with $\mathrm{SH} 2$ domains of the binding partners. To do so, we used a set of GST-fused SH2-domains as a bait in pull-down assay to precipitate SHB from the cell extracts transfected with HA-FAK1. As Fig. 3A shows the overexpression of FAK1 enhanced the interaction of SHB with SH2 domains of CRK, PI3K and

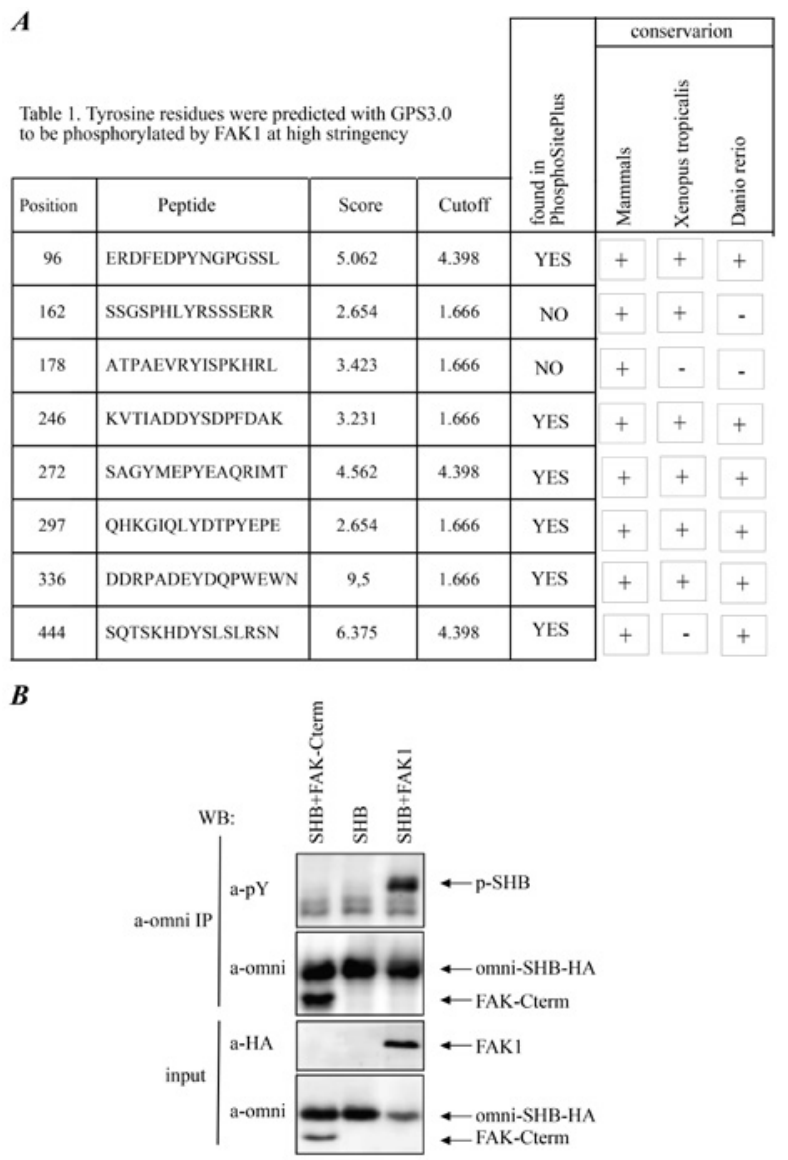

Fig.2. Overexpression of FAK1 kinase induces tyrosine phosphorylation of SHB protein. A. Table representing a list of phosphotyrosine sites of SHB predicted with highest stringency by GPS3.0 to be phosphorylated by FAK1 kinase. Category "mammals" contains Homo sapiens, Mus musculus, Rattus norvegicus, Canis lupus. B. 293 cells were co-transfected with omni-SHBHA, HA-FAK1 or omni-FAK1-Cterm. 24h after transfection cells were harvested, lysed and omni-SHB-HA immunoprecipitated with monoclonal a-omni antibodies from the respective cell extracts. Precipitated material was analyzed by western blot: tyrosine phosphorylated species were detected by monoclonal a-phosphotyrosine antibody, total omni-SHB-HA was visualized by aomni antibody. Two lower panel show immunodetection of omniSHB-HA, full-length and omni-FAK1-Cterm in cell extracts.

ABL while no interaction with $\mathrm{SH} 2$ domain of GRB2 was detected. This fact may evidence that the FAK1dependent SHB phosphorylation specifically triggers the association of different $\mathrm{SH} 2$ domains containing signaling proteins with SHB. Additionally, 


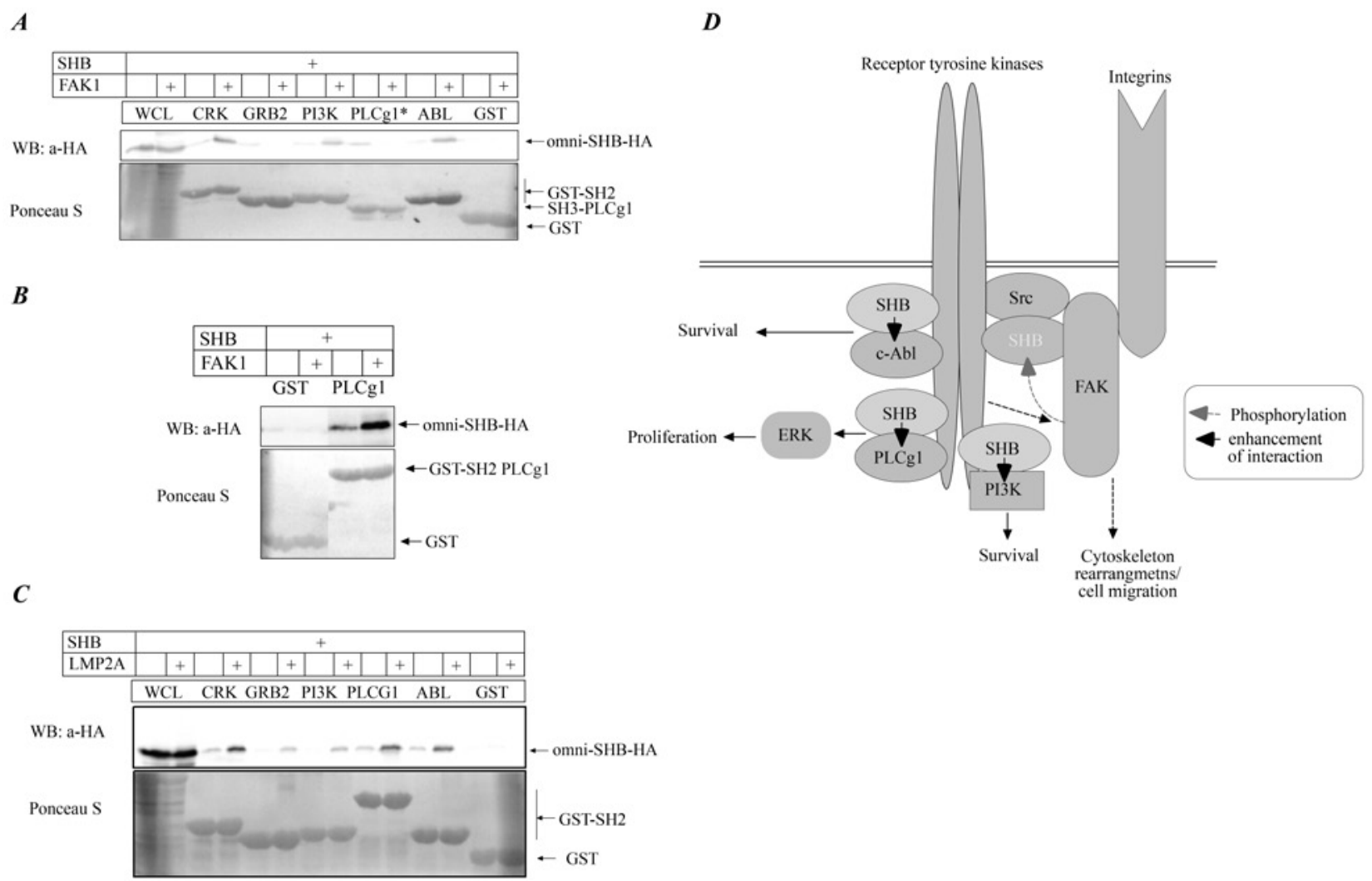

Fig.3. FAK1 and LMP2A regulate association of SHB with SH2-domains. A. Bacterially expressed GST-fused SH2 (A, B and C) or SH3-PLCg1 (A, lanes 9 and 10) of indicated proteins were immobilized on glutathione-beads and incubated with 293 lysates cotransfected with omni-SHB-HA and HA-FAK1 (A and B) or Flag-LMP2A (C) or vector. D. Schematic representation of SHB role in RTKs- and integrin-driven signaling. SHB may directly interact with depicted proteins, with red dashed arrow is shown newly discovered phosphorylation event, FAK1-induced interactions are shown with bold back arrows. Indirect effects are shown with dashed arrows. WCE stands for the whole cell extract.

the interaction of SHB with SH2 domain of PLCg1 was significantly increased upon the FAK1 overexpression but the binding of PLCg1 SH3 domain to SHB was decreased suggesting that the tyrosine phosphorylation of SHB can regulate binding properties of its proline-rich sequences (Fig.3A, lanes 9,10$)$.

The interaction of SHB with PI $3 \mathrm{~K}$ that is mediated by $\mathrm{SH} 2$ domains of latter is of great interest as SHB is required for the activation of the PI3K/AKT pathway [11] and the regulation of cell survival [18]. ABL is a proto-oncogene that encodes a protein tyrosine kinase involved in a variety of cellular processes, including cell division, adhesion, differentiation, and response to stress. In the signaling pathways $\mathrm{ABL}$ is located upstream of PI3K/AKT [19]. A functional significance of phosphorylation-dependent interaction with ABL kinase is enigmatic but recently SHB has been shown to enhance FAK1 activity in the BCR-ABL aberrant cells that caused accelerated disease progression emphasizing the importance of ABL/SHB interplay [9]. It was demonstrated that the interactions between SHB and ABL regulates the ABL kinase activity. The data suggest that $\mathrm{ABL}$ binds to tyrosine phosphorylated SHB via a concerted effort involving both ABL SH3- and SH2-domains and these interactions modulate cell death in response to the genotoxic agents [20]. In general the place of SHB in signaling network is depicted at the Fig. 3D. The activated receptor tyrosine kinases transduce a 
signal to ABL, SRC, phospholipase C and PI3K that results in the cell proliferation or survival depending on the signaling context. SHB is required for the signaling downstream of RTKs and its role depends on the interaction with the protein-partners such as ABL, SRC, GRB2, PI3K and PLCg1. FAK1 is activated by integrins (Fig. 3D) and indirectly by RTKs signaling that leads to the cytoskeleton changes and cell migration [18]. We suggest that the FAK1-induced SHB phosphorylation may be a part of signaling cross-talk between RTKs- and integrin-controlled pathways. Additionally, the augmentation of FAK activity in human tumors, in which it is often overexpressed, occurs through its elevated expression [1], so described here the FAK1-induced effects may be a part of pathological phenotype, e.g. the resistance to apoptosis and invasiveness.

Previously we have shown that the expression of viral protein LMP2A induces the tyrosine phosphorylation of SHB [12]. To address whether the LMP2Ainduced phosphorylation of SHB may have an impact on the SHB binding to the SH2-domain containing proteins we applied a before mentioned approach. As Fig. 3B shows the expression LMP2A strongly enhanced the binding of SHB to a range of the SH2 domains of such proteins as CRK, GRB2, PI3K, PLCg1 and ABL. One can suggest that FAK1 and LMP2A caused the phosphorylation of nonoverlapping sets of tyrosine residues as far as the LMP2A expression enhanced the SHB association with GRB2 but for FAK1 (Fig3 A and B). The described effects of LMP2A and FAK1 expression on the SHB in vitro interaction with before mentioned $\mathrm{SH} 2$ and $\mathrm{SH} 3$ domains could be explained in two ways: 1) both FAK1 and LMP2A cause the SHB phosphorylation at certain sites that are recognized by respective $\mathrm{SH} 2$ domains or 2) FAK1 and LMP2A serve as a scaffold to bring together SHB and before mentioned domains. The later statement is supported by our unpublished observation that LMP2A and FAK1 can interact with SH2-domains of PI3K, ABL and GRB2. From the other hand, the fact that FAK1 negatively regulated SHB binding to the SH3domain of PLCg1 challenges the idea that FAK1 serves simply as an adaptor. Unfortunately, so far it is difficult to uncouple the phosphorylation-induced and potential scaffolding effects of FAK1 on the SHB interaction with its partners.

As far as the expression of both LMP2A and FAK1 strongly upregulated the SHB tyrosine phosphorylation we expected to detect a synergetic effect of co-expression of both proteins with SHB. In addition while the expression of individual proteins elevated SHB phosphorylation level, the co-expression of LMP2A and FAK1 had remarkable negative cooperation effect (Fig.4). The reason for this kind of conclusion is the fact that the most robust effect on the SHB phosphorylation was caused by LMP2A while the co-expression of FAK1 decreased this effect to the FAK1-induced level. One could suggest that FAK1 partially inhibits the activity of Syk and Lyn tyrosine kinases which carry out the LMP2Ainduced SHB phosphorylation [12].

SHB is required for the tonic and serum-independent AKT activation caused by Epstein-Barr virus

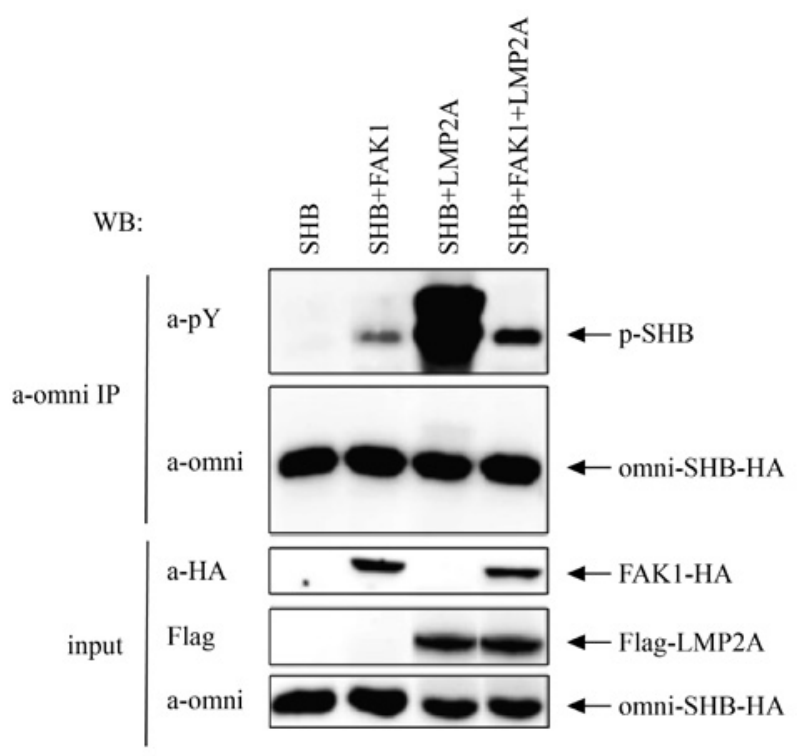

Fig.4. Expression of FAK1 and LMP2A displays negative cooperation effect on the tyrosine phosphorylation levels of SHB. 293 cells were co-transfected with omni-SHB-HA, HAFAK1+control vector or HA-FAK1 and Flag-LMP2A. Levels of SHB tyrosine phosphorylation were estimated as described at figure $2 \mathrm{~B}$. 
Focal adhesion kinase (FAK1) regulates SHB phosphorylation and its binding with a range of signaling proteins.

protein LMP2A [10] and in line with this observation it has been shown that LMP2A induces the SHB tyrosine phosphorylation [12]. We suggest that described here LMP2A-induced interaction of SHB with SH2 domains of PI3K, ABL, PLCg1 may be responsible for the downstream signaling towards AKT and RAS activation. Moreover, it has been shown that LMP2A induces the epithelial cell migration [21] in FAK1-dependent manner [22]. We assume that signaling downstream of FAK1 and LMP2A may converge on SHB. The fact that LMP2A can induce the SHB phosphorylation that triggers SHB binding to GRB2, PLCG1, PI3K and other proteins in this way mimicking the FAK1 activity may represent an important aspect of the LMP2A-induced pathogenicity providing a link between the LMP2Adriven SHB activation and cell migration.

\section{Funding}

This work was supported by joint project between NAS of Ukraine and CNRS "From Molecular to Cellular Events in Human Pathologies" (N0113U002831).

\section{REFERENCES}

1. Mon NN, Ito $S$, Senga T, Hamaguchi M. FAK signaling in neoplastic disorders: a linkage between inflammation and cancer. Ann N Y Acad Sci. 2006;1086:199-212.

2. Xia H, Nho RS, Kahm J, Kleidon J, Henke CA. Focal adhesion kinase is upstream of phosphatidylinositol 3-kinase/ Akt in regulating fibroblast survival in response to contraction of type I collagen matrices via a beta 1 integrin viability signaling pathway. J Biol Chem. 2004;279(31):3302434.

3. Schaller MD. Biochemical signals and biological responses elicited by the focal adhesion kinase. Biochim Biophys Acta. 2001;1540(1):1-21.

4. Chen HC, Guan JL. Association of focal adhesion kinase with its potential substrate phosphatidylinositol 3-kinase. Proc Natl Acad Sci US A. 1994;91(21):10148-52.

5. Chen HC, Appeddu PA, Isoda H, Guan JL. Phosphorylation of tyrosine 397 in focal adhesion kinase is required for binding phosphatidylinositol 3-kinase. $J$ Biol Chem. 1996;271(42):26329-34.

6. Nolan K, Lacoste J, Parsons JT. Regulated expression of focal adhesion kinase-related nonkinase, the autonomously expressed C-terminal domain of focal adhesion kinase. $\mathrm{Mol}$ Cell Biol. 1999;19(9):6120-9.
7. Han DC, Guan JL. Association of focal adhesion kinase with Grb7 and its role in cell migration. J Biol Chem. 1999;274(34):24425-30.

8. Holmqvist $K$, Cross $M$, Riley D, Welsh M. The Shb adaptor protein causes Src-dependent cell spreading and activation of focal adhesion kinase in murine brain endothelial cells. Cell Signal. 2003;15(2):171-9.

9. Gustafsson K, Jamalpour M, Trinh C, Kharas MG, Welsh M. The Src homology-2 protein Shb modulates focal adhesion kinase signaling in a BCR-ABL myeloproliferative disorder causing accelerated progression of disease. J Hematol Oncol. 2014;7:45.

10. Matskova LV, Helmstetter C, Ingham RJ, Gish G, Lindholm CK, Ernberg I, Pawson T, Winberg G. The Shb signalling scaffold binds to and regulates constitutive signals from the Epstein-Barr virus LMP2A membrane protein. Oncogene. 2007;26(34):4908-17.

11. Cross MJ, Lu L, Magnusson P, Nyqvist D, Holmqvist K, Welsh M, Claesson-Welsh L. The Shb adaptor protein binds to tyrosine 766 in the FGFR-1 and regulates the Ras/MEK/ MAPK pathway via FRS2 phosphorylation in endothelial cells. Mol Biol Cell. 2002;13(8):2881-93.

12. Dergai O, Dergai M, Skrypkina I, Matskova L, Tsyba L, Gudkova $D$, Rynditch $A$. The LMP2A protein of Epstein-Barr virus regulates phosphorylation of ITSN1 and Shb adaptors by tyrosine kinases. Cell Signal. 2013;25(1):33-40.

13. Novokhatska O, Dergai M, Tsyba L, Skrypkina I, Filonenko V, Moreau J, Rynditch A. Adaptor proteins intersectin 1 and 2 bind similar proline-rich ligands but are differentially recognized by $\mathrm{SH} 2$ domain-containing proteins. PLoS One. 2013;8(7):e70546.

14. Golubovskaya VM, Zheng $M$, Zhang L, Li JL, Cance WG. The direct effect of focal adhesion kinase (FAK), dominantnegative FAK, FAK-CD and FAK siRNA on gene expression and human MCF-7 breast cancer cell tumorigenesis. BMC Cancer. 2009;9:280.

15. Dergai OV, Dergai MV, Gudkova DO, Tsyba LO, Skrypkina IYa, Rynditch $A V$. Interaction of ubiquitin ligase CBL with LMP2A protein of Epstein-Barr virus occurs via PTB domain of CBL and does not depend on adaptor ITSN1. Biopolym Cell. 2013; 29(2): 131-5.

16. Xue Y, Ren J, Gao X, Jin C, Wen L, Yao X. GPS 2.0, a tool to predict kinase-specific phosphorylation sites in hierarchy. Mol Cell Proteomics. 2008;7(9):1598-608.

17. Pawson T, Gish GD, Nash P. SH2 domains, interaction modules and cellular wiring. Trends Cell Biol. 2001;11(12):504-11.

18. Welsh M, Jamalpour M, Zang G, Akerblom B. The role of the Src Homology-2 domain containing protein B (SHB) in $\beta$ cells. J Mol Endocrinol. 2016;56(1):R21-31.

19. Gesbert F, Sellers WR, Signoretti S, Loda M, Griffin JD. BCR/ $\mathrm{ABL}$ regulates expression of the cyclin-dependent kinase inhibitor p27Kip1 through the phosphatidylinositol 3-Kinase/ AKT pathway. J Biol Chem. 2000;275(50):39223-30. 
20. Hägerkvist R, Mokhtari D, Lindholm C, Farnebo F, Mostoslavsky $G$, Mulligan RC, Welsh $N$, Welsh $M$. Consequences of Shb and c-Abl interactions for cell death in response to various stress stimuli. Exp Cell Res. 2007;313(2):284-91.

21. Lu J, Lin WH, Chen SY, Longnecker R, Tsai SC, Chen CL, Tsai $\mathrm{CH}$. Syk tyrosine kinase mediates Epstein-Barr virus latent membrane protein 2A-induced cell migration in epithelial cells. J Biol Chem. 2006;281(13):8806-14.

22. Fotheringham JA, Coalson NE, Raab-Traub N. EpsteinBarr virus latent membrane protein-2A induces ITAM/Sykand Akt-dependent epithelial migration through $\alpha \mathrm{v}$-integrin membrane translocation. J Virol. 2012;86(19):10308-20.

\section{Кіназа фокальної адгезії (FAK1) регулюс фосфорилювання адаптерного білка SHB та його взасмодію 3 низкою сигнальних білків.}

О. В. Дергай, А. М. Яручик, А. В. Риндич

Мета. Дослідити ефект надексперсії кінази фокальної адгезії (FAK1) на рівнь фосфорилювання залишків тирозину адапторного білка SHB та знайти функціональне значення цієї посттрансляційної модифікації. Методи. Конструювання рекомбінантних ДНК, експресія та очистка рекомбінантних білків, трасфекція клітинних ліній, вестерн блот. Результати. Надексперсія FAK1 в клітинах лінії 293 викликає масивне фосфорилювання залишків тирозину адапторного білка SHB та значно підсилює його взаємодію in vitro з $\mathrm{SH} 2$-доменами низки сигнальних білків, таких як PI3K, ABL, CRK та PLCg1. Крім того, білок LMP2A вірусу Епштейна-Барр може посилювати in vitro зв'язування SHB з вищезазначеними білками, так само, як i FAK1. Тоді як надекспресія окремих білків FAK1 та LMP2A підвищувала рівні фосфорилювання SHB, їх ко-експерсія не мала синергічного ефекту. Висновки. Експресія FAK1 та LMP2A індукує фосфорилювання залишків тирозину адаптор- ного білка $\mathrm{SHB}$ та підсилює його взаємодію з $\mathrm{SH} 2$-доменами низки сигнальних білків.

Кл юч о в і с л о в а: FAK1, SHB, LMP2A, фосфорилювання.

Киназа фокальной адгезии (FAK1) регулирует фосфорилирование адаптерного белка SHB и его взаимодействие с рядом сигнальных белков.

А. В. Дергай, А. М. Яручик, А. В. Рындич

Цель. Исследовать эффект суперэкспрессии киназы фокальной адгезии (FAK1) на уровень фосфорилирования остатков тирозина адаптерного белка SHB и найти функциональное значение этой посттрансляционной модификации. Методы. Конструирование рекомбинантных ДНК, экспрессия и очистка рекомбинантных белков, трансфекция клеточных линий, вестерн блот. Результаты. Суперэксперссия FAK1 в клетках линии 293 приводит к многократному повышению уровней фосфорилирования остатков тирозина адаптерного белка SHB, что в свою очередь приводит к усилению взаимодейсвия с $\mathrm{SH} 2$ доменами ряда сигнальных белков, таких как PI3K, ABL, CRK та PLCg1. Кроме того, белок LMP2A вируса Эпштейна-Барр может усиливать in vitro взаимодействие SHB с указанными белками, аналогично FAK1. Тогда как суперэкспрессия отдельных белков FAK1 та LMP2A приводила к интенсификации фосфорилирования SHB, их ко-экспрессия не обладала синергическим эффектом. Выводы. Экспрессия FAK1 и LMP2A индуцирует фософрилирование остатков тирозина адаптерного белка SHB и усиливает его взаимодействие с $\mathrm{SH} 2$-доменами ряда сигнальных белков.

К л юч е в ы е с л о в а: FAK1, SHB, LMP2A, фосфорилирование.

Received 12.12.2015 